\title{
Isolation and Biochemical Characterization of Plant Growth Promoting Bacteria from a Maize Crop Field
}

\author{
Prashantkumar S. Chakra ${ }^{1}$, P.G. Vinay Kumar ${ }^{1}$ and CT. Swamy ${ }^{2 *}$ \\ ${ }^{1}$ Department of Microbiology, Davangere University, Shivagangothri, \\ Davanagere-577007, India \\ ${ }^{2}$ Department of Biotechnology, Davangere University, Shivagangothri, \\ Davanagere-577007, India \\ *Corresponding author
}

A B S T R A C T

\section{Keywords \\ PGPR, $\mathrm{N}_{2}$ Fixation, \\ Ammonia \\ production, IAA, \\ Siderophore and \\ AIBS \\ Article Info \\ Accepted: \\ 12 March 2019 \\ Available Online: \\ 10 April 2019}

Plant growth-promoting rhizobacteria (PGPR) are used as alternatives to the chemical fertilizers to increase crop yield in agriculture. The present study was undertaken to isolate, screen and evaluate selected promising PGPR isolates from maize fields. Out of 30 bacterial isolates, four most promising isolates (SP-01 to SP-04) have analysed for the various PGP traits. Bacterial isolate SP-03 showed the maximum PGP traits like $\mathrm{N}_{2}$ fixation, IAA production, ammonia production and siderophore production in in-vitro condition. To identify the isolates morphological and biochemical tests were performed and analysed in the ABIS online biochemical identification system. These analysis confirmed isolates belonged to Brevibacillus sp. and Panibacillus sp. As per our knowledge, the present study one among the few studies of Brevibacillus and Panibacillus sp. which exhibit various PGP traits.

\section{Introduction}

Plant Growth Promoting Rhizobacteria (PGPR), which enhances plant growth and increase crop yield via secretion of various plant growth promoting substances as well as biofertilizers. PGPR's exhibit antagonistic effects to soil-borne pathogens or induce the systemic resistance against pathogens in the entire plant lifespan. A wide range of bacteria colonizes in the root as well as other parts of plant-like roots, stems, leaves, seeds, and fruits (Ryan et al., 2018). The bacterial community inhabiting, rhizosphere region perhaps source of formation of the community of endophytic bacteria in the plant (Hardoim et al., 2008).

The rhizosphere region is a major hot spot of microbial interactions because of plant root exudates released by the plant acts as a food source for microorganisms and a driving force of their population density and activities (Klemedtsson et al., 1988; Berendsen et al., 2012). 
Antagonistic rhizobacteria produce several substances like siderophores and antibiotics, which indirectly promotes the growth in many plants by controlling plant pathogens. In plants pathogen-induced systemic acquired resistance (SAR) resembles with induced systemic resistance (ISR) when the inducing bacteria and the challenging pathogen remain spatially separated. Both types of induced resistance render uninfected plant parts more resistant to pathogens in several plant species. Rhizobacteria induce resistance through the salicylic acid-dependent SAR pathway or require jasmonic acid and ethylene perception from the plant for ISR (Beneduzi et al., 2012).

Several bacterial spp. has been utilized as PGPR such as Agrobacterium, Arthrobacter, Azotobacter, Azospirillum, Bacillus, Burkholderia, Caulobacter, Chromobacterium, Erwinia, Flavobacterium, Micrococcus, Pseudomonas, and Serratia (Bhattacharyya and Jha, 2012). Diversified Bacillus spp. Occurred in agricultural fields contribute to crop productivity by direct or indirect mechanisms. The major direct mechanisms of plant growth promotion include the production of phytohormones, phosphate solubilization and mobilization, siderophore production, antibiotics and induction of plant systemic resistance to pathogens (Kumar et al., 2011). Indirect plant growth mechanisms include control of plant pathogens and deleterious rhizosphere inhabiting microbes (Karimi et al., 2012; Xiang et al., 2017).

In the present study, we collected a soil sample from maize field serially diluted in sterile water and $0.1 \mathrm{ml}$ of aliquot spread on Nitrogen free Bromothymol blue $(\mathrm{NFb})$ and Pikovskaya's medium and incubated at $30{ }^{\circ} \mathrm{C}$. Later bacterial colonies were selected and subjected to evaluate the plant growth promoting properties.

\section{Materials and Methods}

\section{Collection of soil sample}

Soil samples were collected from rhizosphere (Maize) and Non-rhizosphere regions, from the agriculture land at the depth of 6 to $12 \mathrm{~cm}$. Collected soil samples were stored in polythene bags aseptically.

\section{Isolation of plant growth promoting bacteria}

For isolation of plant growth promoting bacteria, $1 \mathrm{~g}$ of rhizosphere and nonrhizosphere soil was suspended in $10 \mathrm{ml}$ of sterile water and then serially diluted and transferred to $\mathrm{NFb}$ and Pikovskaya's media by spread plate technique and incubated in an inverted position at $30{ }^{\circ} \mathrm{C}$ for $28-48 \mathrm{hrs}$. Isolated colonies appearing on agar plates were transferred to slants for further study.

\section{Biochemical characterization of PGPR bacteria}

Different biochemical parameters were performed to identify bacterial isolates. Preliminarily, Gram's staining technique, motility, growth at $5 \% \mathrm{NaCl}$ along with Indole production test, Methyl red (MR) and Voges-Proskauer's (VP) test, Citrate utilization test, Catalase test, Starch hydrolysis test, Gelatine liquefaction test, Oxidase test, Nitrate Reduction test, and Carbohydrate fermentation tests were performed.

\section{Plant growth promoting parameters of bacteria}

\section{Nitrogen fixation assay on NFb medium}

Isolated bacteria were screened on $\mathrm{NFb}$ solid medium for nitrogen fixation activity. The composition of $\mathrm{NFb}(\mathrm{g} / \mathrm{l})$ : DL-Malic acid 5.0, 
$\mathrm{KOH} 4.0, \mathrm{~K}_{2} \mathrm{HPO}_{4} \quad 0.5, \mathrm{FeSO}_{4} 7 \mathrm{H}_{2} \mathrm{O} \quad 0.05$, $\mathrm{MnSO}_{4} \mathrm{H}_{2} \mathrm{O} \quad 0.01, \quad \mathrm{MgSO}_{4} 7 \mathrm{H}_{2} \mathrm{O} \quad 0.1, \quad \mathrm{NaCl}$ $0.02, \quad \mathrm{CaCl}_{2} 2 \mathrm{H}_{2} \mathrm{O} \quad 0.01, \quad \mathrm{Na}_{2} \mathrm{MoO}_{4} \cdot 2 \mathrm{H}_{2} \mathrm{O}$ 0.002 , Bromothymol blue $2 \mathrm{ml} \quad(0.5 \%$ alcoholic solution), Agar-agar 15, Distilled water $1000 \mathrm{ml}$, and $\mathrm{pH}$ 6.8). Isolates showed blue colour zone around the colony considered as positive for nitrogen fixation (Swamy et al., 2016).

\section{Phosphate solubilization}

On phosphate solubilization activity the bacterial isolates were inoculated on $\mathrm{Pi}$ solid medium and incubated $\left(30^{\circ} \mathrm{C} / 48 \mathrm{hr}\right)$. Further, the zone of clearance around the colony was observed for phosphate solubilization (Nautiyal et al., 2000).

\section{Ammonia production}

Ammonia production was carried out according to Cappuccino and Sherman (1992). The bacterial isolates inoculated to peptone water and incubated at $30{ }^{\circ} \mathrm{C} / 48 \mathrm{hr}$.

After incubation, $1 \mathrm{ml}$ of Nessler's reagent was added to each vials and ammonia production has qualitatively detected by colour development.

\section{Indoleacetic acid (IAA) assay}

3-Indoleacetic acid (IAA) assay has conducted in Tryptone yeast extract broth with tryptophan. Bacterial isolates were inoculated and incubated at $30^{\circ} \mathrm{C} / 48 \mathrm{hr}$. The bacterial culture was centrifuged $(10,000 \mathrm{~g}$ for $\sim 20 \mathrm{~min}$ ) and the supernatant was collected then performed the Salkowski method.

The pink colour production has visually observed and measured the colour intensity at $540 \mathrm{~nm}$ in the spectrophotometer (Swamy et al., 2016).

\section{Siderophore production assay}

The isolates were screened for siderophore production by the universal chemical assay (chrome azurol S assay). Glasswares used in this study were washed in $6 \mathrm{M} \mathrm{HCl}$ to remove traces of contaminating iron and then rinsed thoroughly with distilled water. Autoclaved CAS-HDTMA and MM9 media were plated and incubated for $24 \mathrm{hr}$ at $30{ }^{\circ} \mathrm{C}$ for the detection of contamination. Later, the isolates were spot inoculated to CAS agar plates and incubated at $30{ }^{\circ} \mathrm{C}$ for $72 \mathrm{hr}$. The isolates producing orange colour with of halo zone around the colonies were considered as siderophore producers (Milagres et al., 1999; Pérez-Miranda et al., 2007; Ahmad et al., 2008).

\section{Results and Discussion}

\section{Isolation of plant growth promoting bacteria}

A total of 30 bacterial colonies were isolated on both NFb and Pikovskaya's agar medium from the maize crop field. Out of 30 isolates 4 potential isolates i.e SP-01, SP-02, SP-03 and SP-04 showed PGPR activities were selected for the further studies. Soil contains a wide range of PGP bacteria helpful to plants in many ways and several previous studies employed serial dilution method to isolate the PGPR from soil samples (Gettha et al., 2014; Verma and shahi 2015).

\section{Biochemical characterization of PGPR bacteria}

Biochemical tests were done for the isolates showed PGP traits and the results were tabulated (Table 1). Based on the morphological and biochemical analysis, isolates were confirmed as Brevibacillus sp. The rhizosphere bacterial isolates were characterized by biochemical attributes and 
were identified as SP-01 (Brevibacillus brevis $\sim 97.2 \%$ similarity), SP-02 (Brevibacillus brevis $\quad \sim 97.2 \% \quad$ similarity), SP-03 (Brevibacillus brevis $\sim 96.9 \%$ similarity) and SP-04 (Bacillus aeolius $~ 85 \%$ similarity) on the basis of ABIS online software (Table 1). Bacillus and Paenibacillus strains plant growth promoting traits have been widely studied for enhancement of plant growth (Choudhary and Johri 2008; Dev et al., 2016).

\section{Plant growth promoting parameters of bacteria}

The four potential isolates were screened for their ability to fix nitrogen on the $\mathrm{NFb}$ solid medium in which SP-03 isolate gave a maximum zone of colour than other isolates (SP-01, 02 and 04 who had also shown nitrogen fixation activity (Figure 1 and 2). The nitrogen fixation was assessed by acetylene reduction assay showed a variation which ranged from 3.57 to $9.25 \mu \mathrm{mol} \mathrm{C}_{2} \mathrm{H}_{4}$ formed $/ \mathrm{mg}$ protein $/ \mathrm{h}$ and also analysed their plant growth promoting characters (Damodara chari et al., 2015).
Phosphate solubilizing activity was estimated by point inoculating of bacteria. Out of 30 bacterial isolates, only SP-02 showed maximum activity with $30 \mathrm{~mm}$ in diameter on Pikovskaya's agar medium (Figure 3). The maximum phosphate solubilization was recorded from the Bacillus and Pseudomonas sp. from the saline soil (Lamizadeh et al., 2016).

The qualitative determination of ammonia production was recorded from the all 04 bacterial isolates, however, SP-02 showed the brown colour indicates maximum ammonia production.

All 30 bacterial isolates were subjected to IAA production and IAA was detected in the supernatant of ten isolates (Figure 4). Among the ten isolates, maximum IAA production recorded from four isolates (SP-01 to 04). Bacillus, Paenibacillus and Pseudomonas strains were isolated from saline and nonsaline soil showed a wide range of PGP traits and exhibited maximum phosphate solubilization (Lamizadeh et al., 2016).

Table.1 Biochemical characteristics of bacterial isolates

\begin{tabular}{|l|l|l|l|l|l|}
\hline Sl.No. & Biochemical characteristics & SP-01 & SP-02 & SP-03 & SP-04 \\
\hline $\mathbf{0 1}$ & Gram reaction & + & + & + & + \\
\hline $\mathbf{0 2}$ & Shape & Bacilli & Bacilli & Bacilli & Bacilli \\
\hline $\mathbf{0 3}$ & Motility & Motile & Motile & Motile & Motile \\
\hline $\mathbf{0 4}$ & Growth at 5\% Nacl & - & - & - & - \\
\hline $\mathbf{0 5}$ & Catalase & + & + & + & - \\
\hline $\mathbf{0 6}$ & KOH Solubility & - & - & - & - \\
\hline $\mathbf{0 7}$ & Oxidase & + & + & + & + \\
\hline $\mathbf{0 8}$ & Indole & - & - & - & - \\
\hline $\mathbf{0 9}$ & Methyl red & + & + & + & - \\
\hline $\mathbf{1 0}$ & Voges Prauskeur's test & - & - & - & - \\
\hline $\mathbf{1 1}$ & Citrate & + & - & + & - \\
\hline $\mathbf{1 2}$ & Nitrate & - & + & + & + \\
\hline $\mathbf{1 3}$ & Gelatin & + & + & + & + \\
\hline $\mathbf{1 4}$ & Starch hydrolysis & - & - & - & + \\
\hline $\mathbf{1 5}$ & Glucose fermentation & + & + & + & + \\
\hline $\mathbf{1 6}$ & Mannitol fermentation & + & + & + & + \\
\hline $\mathbf{1 7}$ & Sucrose fermentation & - & - & - & - \\
\hline & & & & & \\
\hline
\end{tabular}


Fig.1 and 2 Rhizosphere isolates nitrogen fixation on $\mathrm{NFb}$ medium and zone of colouration in $\mathrm{mm}$
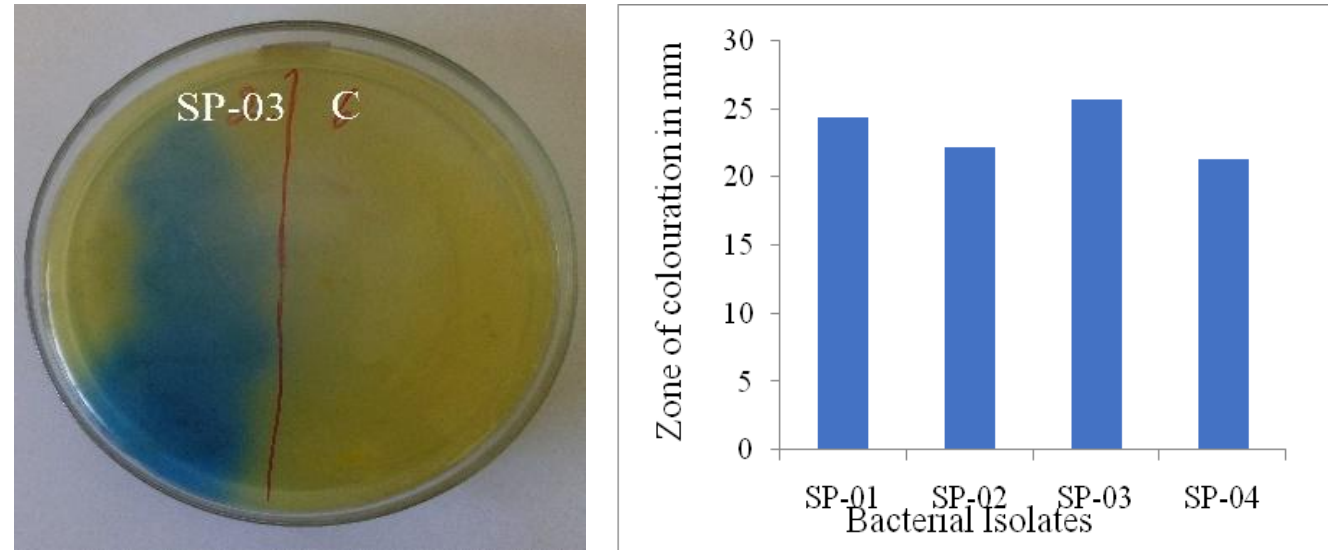

Fig.3 Phosphate solubilization on Pikovskaya's agar medium (Zone of clearance in mm)

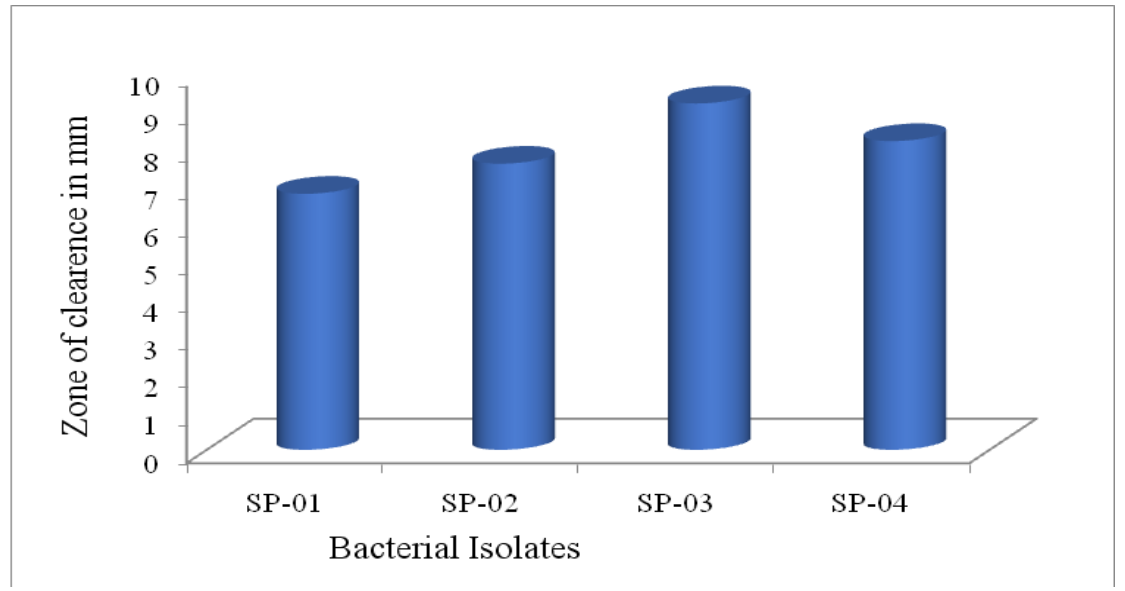

Fig.4 IAA production by Salkowsky's method (pink colour development)
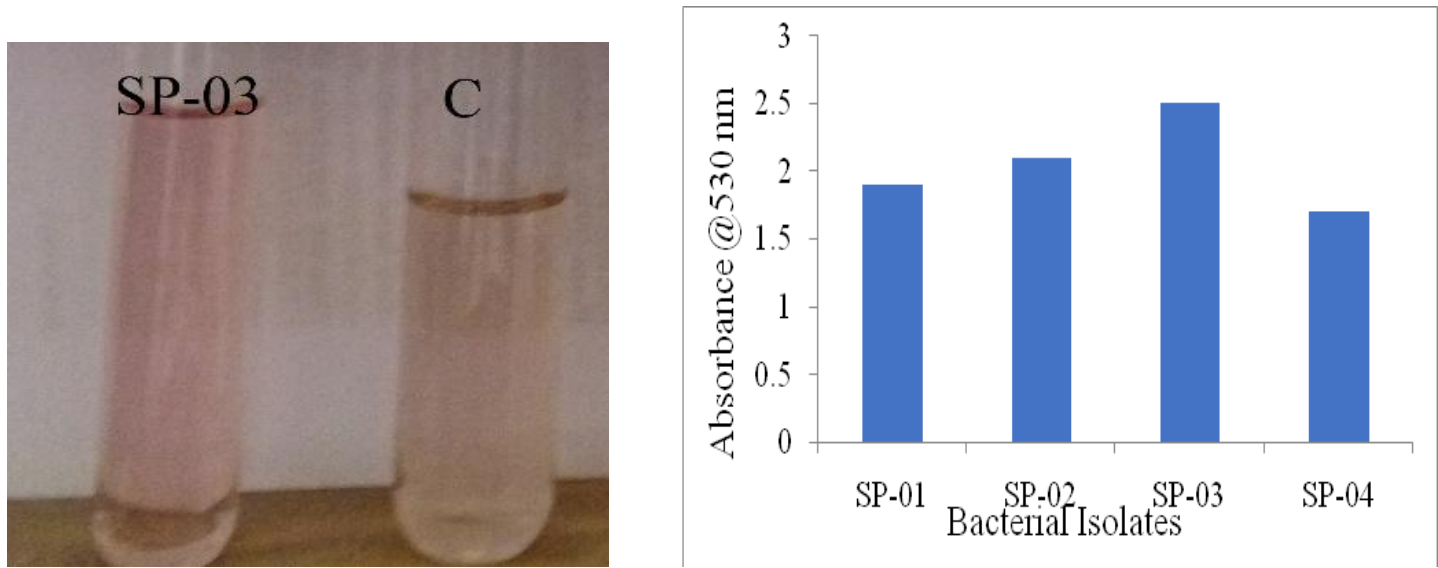
Fig.5 Siderophore production on CAS-HDTMA MM9 medium

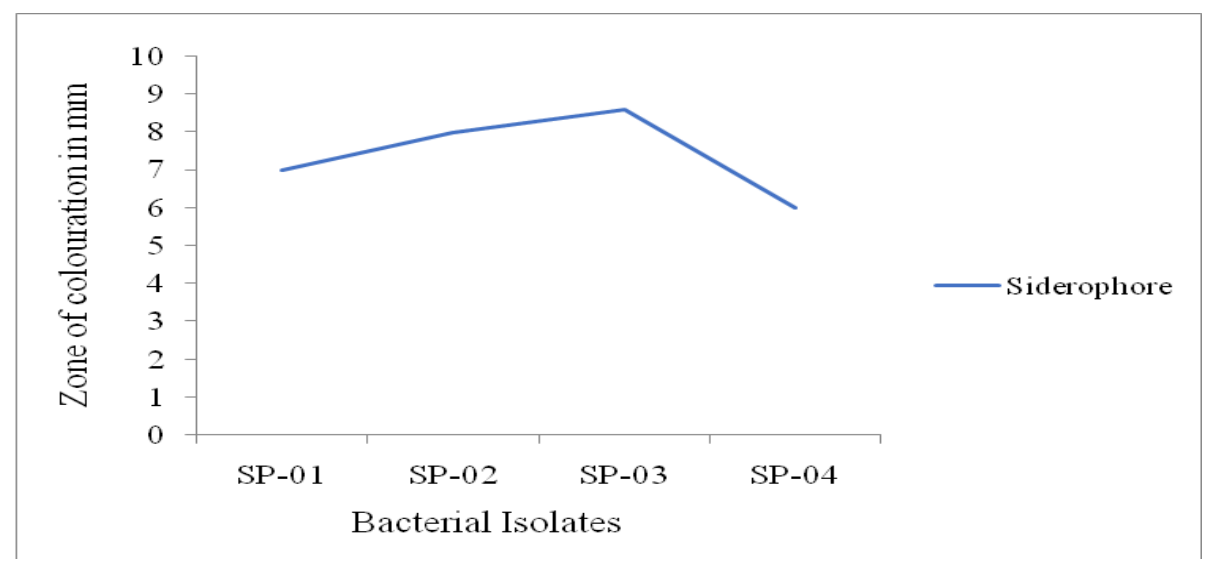

Bacterial isolates produced orange halos around the colonies on blue were considered as positive for siderophore production. In this study, there are 7 isolates showed siderophore production positive however, maximum halos observed in isolate SP-03 followed by SP-02 (Figure 5). Siderophore producing Bacillus isolates also exhibited different PGPR activities and enhances the plant growth in vegetable plants (Pahari and Mishra, 2017).

In conclusion, plant growth promoting bacteria play a variety of functions in the growth and development of plant as well as crop yield increases in agriculture. In this study, PGPR isolate SP-03 showed maximum PGP traits in in-vitro condition perhaps used as a plant growth promoter in agriculture crops. Along with SP-03, other 3 isolates (SP01, 02 and 04) were also exhibited slight less activity of PGP traits. All these four bacterial isolates used as a bio-fertilizer in various crops after proper validation. Only few studies were reported on PGPR traits of Brevibacillus spp., among these studies present report also flood a lime light on PGP Traits of the same spp.

\section{References}

Bernardeau, M., Vernoux, J. P., HenriDubernet, S. and Gue' guen, M. 2008
Safety assessment of dairy microorganisms: the Lactobacillus genus. Int. J. Food Microbiol., 126: 278-285.

Ryan, R.P., Germaine, K., Franks, A., Ryan, D.J. and Dowling, D.N. 2008. Bacterial endophytes: recent developments and applications. FEMS microbiology letters, 278(1):1-9.

Hardoim, P.R., van Overbeek, L.S. and van Elsas, J.D. 2008. Properties of bacterial endophytes and their proposed role in plant growth. Trends in microbiology, 16(10):463-471.

Berendsen, R.L., Pieterse, C.M. and Bakker, P.A. 2012. The rhizosphere microbiome and plant health. Trends in plant science, 17(8):478-486.

Klemedtsson, L., Svensson, B.H. and Rosswall, T. 1988. Relationships between soil moisture content and nitrous oxide production during nitrification and denitrification Biology and Fertility of Soils, 6(2):106-111.

Nautiyal, C.S., Bhadauria, S., Kumar, P., Lal, H., Mondal, R. and Verma, D. 2000. Stress induced phosphate solubilization in bacteria isolated from alkaline soils. FEMS Microbiology Letters, 182(2):291-296.

Cappuccino, J.G., Sherman, N. 1992. 
Biochemical activities of microorganisms. In: Microbiology, A Laboratory Manual., The Pearson Education (Singapore) Pvt. Ltd Patparganj, Delhi.

Ahmad, F., Ahmad, I. and Khan, M.S. 2008. Screening of free-living rhizospheric bacteria for their multiple plant growth promoting activities. Microbiological research, 163(2):173-181.

Milagres, A.M., Machuca, A. and Napoleao, D., 1999. Detection of siderophore production from several fungi and bacteria by a modification of chrome azurol S (CAS) agar plate assay. Journal of Microbiological Methods, 37(1):1-6.

Pérez-Miranda, S., Cabirol, N., GeorgeTéllez, R., Zamudio-Rivera, L.S. and Fernández, F.J., 2007. O-CAS, a fast and universal method for siderophore detection. Journal of microbiological methods, 70(1):127-131.

Kumar, A., Prakash, A. and Johri, B.N. 2011. Bacillus as PGPR in crop ecosystem. In Bacteria in agrobiology: crop ecosystems (pp. 37-59). Springer, Berlin, Heidelberg.

Bhattacharyya, P.N. and Jha, D.K. 2012. Plant growth-promoting rhizobacteria (PGPR): emergence in agriculture. World Journal of Microbiology and Biotechnology, 28(4):1327-1350.

Karimi, K., Amini, J., Harighi, B. and Bahramnejad, B. 2012. Evaluation of biocontrol potential of'pseudomonas' and'bacillus' spp. against fusarium wilt of chickpea. Australian Journal of Crop Science, 6(4):695.

Xiang, N., Lawrence, K.S., Kloepper, J.W., Donald, P.A., McInroy, J.A. and Lawrence, G.W. 2017. Biological control of Meloidogyne incognita by spore-forming plant growth-promoting rhizobacteria on cotton. Plant disease, 101(5):774-784.
Pahari, A. and Mishra, B.B., 2017. Characterization of siderophore producing Rhizobacteria and Its effect on growth performance of different vegetables. Int. J. Curr. Microbiol. App. Sci, 6(5):1398-1405.

Dev, S.S., Nisha, E.A. and Venu, A. 2016. Biochemical and molecular characterization of efficient phytase producing bacterial isolates from soil samples. International Journal of Current Microbiology and Applied Sciences, 5(5):218-226.

Damodara chari, K., Subhash Reddy, R., and Trimurtulu N. 2015. Screening and characterization of diazotrophic bacterial isolates for plant growth promoting properties. Int.J.Curr. Microbiol.App.Sci., 4(9):704-710.

Geetha, K., Venkatesham, E., Hindumathi A., and Bhadraiah, B. 2014. Isolation, screening and characterization of plant growth promoting bacteria and their effect on Vigna Radita (L.) R.Wilczek. Int.J.Curr.Microbiol.App. Sci, 3(6):799-809.

Verma, P., and Shahi, SK. 2015. Isolation and Characterization of bacterial isolates from Potato rhizosphere as potent plant growth promoters. Int.J.Curr.Microbiol.App.Sci, $\quad 4(3)$ : 521-528.

Choudhary, DK., and Johri, BN. 2008 Interactions of Bacillus spp. and plants - with special reference to induced systemic resistance (ISR). Microbiol Res 164:493-513.

Swamy, C.T., Gayathri, D., Devaraja, T.N., Bandekar, M., D'Souza, S.E., Meena, R.M. and Ramaiah, N., 2016. Plant growth promoting potential and phylogenetic characteristics of a lichenized nitrogen fixing bacterium, Enterobacter cloacae. Journal of basic microbiology, 56(12):13691379. 
Beneduzi, A., Peres, D., Vargas, L.K., Bodanese-Zanettini, M.H. and Passaglia, L.M.P. 2008. Evaluation of genetic diversity and plant growth promoting activities of nitrogen-fixing bacilli isolated from rice fields in South Brazil. Applied Soil Ecology, 39(3):311-320.

Lamizadeh, E., Enayatizamir, N. and
Motamedi, H. 2016. Isolation and identification of plant growthpromoting rhizobacteria (PGPR) from the rhizosphere of sugarcane in saline and non-saline soil. International Journal of Current Microbiology and Applied Sciences, 5(10):1072-83.

\section{How to cite this article:}

Prashantkumar S. Chakra, P.G. Vinay Kumar and Swamy, CT. 2019. Isolation and Biochemical Characterization of Plant Growth Promoting Bacteria from a Maize Crop Field. Int.J.Curr.Microbiol.App.Sci. 8(04): 1415-1422. doi: https://doi.org/10.20546/ijcmas.2019.804.164 